\title{
PROYEKSI GEOMETRI FUZZY PADA RUANG
}

\author{
Muhammad Izzat Ubaidillah \\ Mahasiswa Jurusan Matematika UIN Maulana Malik Ibrahim Malang \\ e-mail: IzzatBja@yahoo.co.id
}

\begin{abstract}
ABSTRAK
Geometri fuzzy merupakan perkembangan dari geometri tegas, yang mana pada geometri tegas unsur-unsurnya hanya ada dan tidak ada, akan tetapi pada geometri fuzzy unsur-unsur tersebut berkembang dengan ketebalan yang dimiliki oleh masing-masing unsur tersebut. Proyeksi geometri tegas merupakan pembentukan bayangan suatu unsur geometri yang diproyeksikan terhadap unsur proyektor, dengan sifat tegak lurus yang diwakili oleh masing-masing unsurnya, pembahasannya difokuskan pada koordinat hasil proyeksi. Sedangkan proyeksi geometri fuzzy mempunyai pembahasan yang lebih luas, yang mencakup tentang koordinat hasil proyeksi, keeratan relasi masing-masing unsur dan ketebalan masing-masing unsur tersebut. Penelitian ini dilakukan untuk mendeskripsikan dan menganalisis prosedur proyeksi geometri fuzzy pada ruang serta menjelaskan perbedaan antara proyeksi geometri tegas dan proyeksi geometri fuzzy pada ruang.
\end{abstract}

Kata kunci: Geometr Fuzzy, Proyeksi Geometri Fuzzy, Relasi Fuzzy.

\section{ABSTRACT}

Fuzzy geometry is an outgrowth of crisp geometry, which in crisp geometry elements are exist and not exist, but also while on fuzzy geometry elements are developed by thickness which is owned by each of these elements. Crisp projective geometries is the formation of a shadow of geometries element projected on the projectors element, with perpendicular properties which are represented by their respective elemental, the discussion focused on the results of the projection coordinates. While the fuzzy projective geometries have richer discussion, which includes about coordinates of projection results, the mutual relation of each element and the thickness of each element. This research was conducted to describe and analyzing procedure fuzzy projective geometries on the plane and explain the differences between crisp projective geometries and fuzzy projective geometries on plane.

Keywords: Fuzzy Geometry, Fuzzy Relations, Fuzzy Projection Geometries

\section{PENDAHULUAN}

Teori himpunan fuzzy merupakan perluasan dari teori himpunan tegas. Pada teori himpunan tegas, keberadaan suatu elemen pada suatu himpunan $A$ hanya akan memiliki dua kemungkinan keanggotaan, yaitu menjadi anggota $A$ atau tidak menjadi anggota $A$. Suatu nilai yang menunjukkan seberapa besar tingkat keanggotaan suatu elemen $(x)$ dalam suatu himpunan $(A)$, sering dikenal dengan nama derajat keanggotaan dinotasikan dengan $\mu_{A}(x)$. Pada himpunan tegas, hanya ada dua nilai keanggotaan, yaitu $\mu_{A}(x)=1$ untuk $x$ anggota $A$, dan $\mu_{A}(x)=0$ untuk $x$ bukan anggota $A$. Himpunan fuzzy didasarkan pada gagasan untuk memperluas jangkauan fungsi keanggotaan sedemikian hingga fungsi stersebut akan mencakup bilangan real pada interval $[0,1]$, dengan demikian menunjukkan bahwa derajat keanggotaan suatu elemen $(x)$ dalam suatu himpunan $(A)$ tidak hanya ada 0 dan 1 , namun juga nilai yang terletak di dalamnya (Kusumadewi, 2002). Berdasarkan teori tersebut, titik dan garis yang pada geometri tegas hanya ada dan tidak ada, maka dalam geometri fuzzy akan berkembang, titik dan garis tidak hanya direpresentasikan dengan ada dan tidak ada, tetapi berkembang dengan ketebalan yang berbeda.

\section{KAJIAN TEORI}

\section{A. Proyeksi Geometri Tegas}

Pembahasan proyeksi tegas pada ruang terdiri dari tiga poin, yaitu proyeksi titik ke garis, titik ke bidang, dan proyeksi garis ke bidang.

\section{Proyeksi Titik ke Garis}

Proyeksi titik ke garis merupakan pembentukan bayangan suatu titik terhadap suatu garis proyektor, dengan syarat garis hubung titik dengan titik hasil proyeksinya harus tegak lurus dengan garis proyektor. Sedangkan hasil proyeksi yang berupa bayangan titik tersebut dapat ditemukan koordinatnya, dengan diketahui koordinat titik yang diproyeksikan dan persamaan garis proyektornya. 


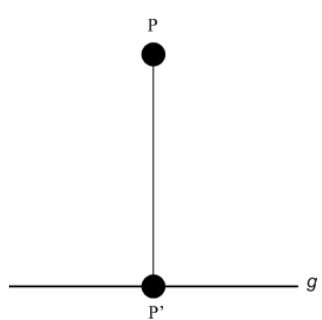

Gambar 1. Proyeksi Titik ke Garis

\section{Proyeksi Titik ke Bidang}

Proyeksi titik ke bidang merupakan pembentukan bayangan suatu titik terhadap suatu bidang proyektor, dengan syarat garis hubung titik dengan titik hasil proyeksinya harus tegak lurus dengan bidang proyektor. Sedangkan hasil proyeksi yang berupa bayangan titik tersebut dapat ditemukan koordinatnya, dengan diketahui koordinat titik yang diproyeksikan dan persamaan bidang proyektornya.

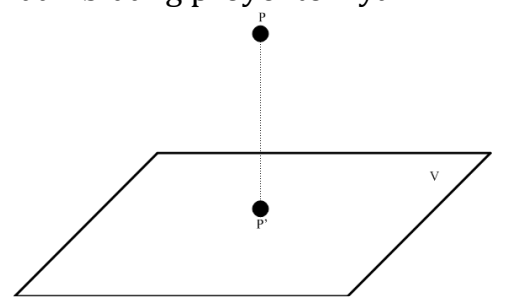

Gambar 2. Proyeksi Titik ke Bidang

\section{Proyeksi Garis ke Bidang}

Proyeksi garis ke bidang merupakan pembentukan bayangan suatu garis yang diproyeksikan terhadap bidang proyektor, dengan sifat tegak lurus yang diwakili oleh masing-masing unsurnya.

Pada proyeksi garis ke bidang terdapat tiga kemungkinan, yaitu garis yang diproyeksikan tegak lurus dengan bidang proyektor, garis yang diproyeksikan sejajar dengan bidang proyektor, dan garis yang diproyeksikan tidak tegak lurus dan tidak sejajar dengan bidang proyektor.

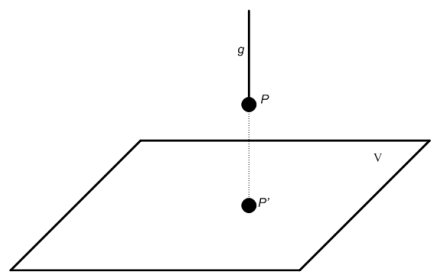

Gambar 3. Proyeksi Garis yang Tegak Lurus dengan Bidang Proyektor

Proyeksi garis ke bidang, dimana garis yang di proyeksikan saling tegak lurus dengan bidang. Proyeksinya diwakili titik, dan hasilnya juga berupa titik bukan berupa garis.
Kemungkinan proyeksi ini terjadi jika garis saling tegak lurus dengan setiap garis pada bidang (Krismanto, 2008).

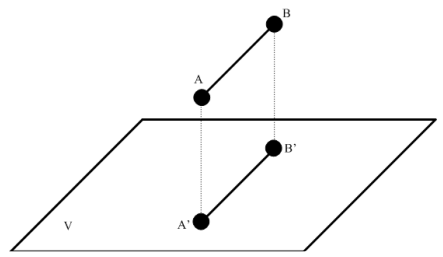

Gambar 4. Proyeksi Garis yang Sejajar dengan Bidang Proyektor

Proyeksi garis ke bidang, dimana garis yang diproyeksikan sejajar dengan bidang proyektor, proyeksi ini terjadi bila garis dan bidang tidak mempunyai titik potong. Hasil proyeksi ini didapatkan misalnya titik A dan B terletak pada garis, titik A' dan B' merupakan proyeksi titik A dan B pada bidang. Ruas garis $\mathrm{A}^{\prime} \mathrm{B}$ ' adalah proyeksi garis pada bidang.

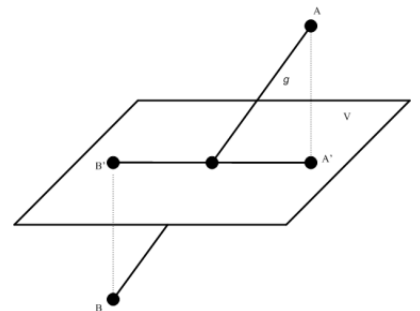

Gambar 5. Proyeksi Garis yang Tidak Tegak Lurus dan Tidak Sejajar dengan Bidang Proyektor

Proyeksi garis ke bidang, dimana garis yang diproyeksikan tidak saling tegak lurus dan tidak sejajar dengan bidang proyektor. Untuk hasil proyeksinya diwakili titik $A$ dan titik $B$ dan hasilnya berupa titik $A^{\prime}$ dan titik $B^{\prime}$ yang apabila dihubungkan menjadi garis $A^{\prime} B^{\prime}$. Kemungkinan ini terjadi jika terdapat garis tidak tegak lurus dengan bidang, serta garis menembus bidang (Krismanto, 2008).

\section{B. Teori Himpunan Fuzzy}

Menurut Kusumadewi dkk (2006), teori himpunan fuzzy merupakan kerangka matematis yang digunakan untuk mempresentasikan ketidakpastian, dan ketidakjelasan karena nilai kebenarannya tidak hanya bernilai benar atau salah. Nilai 0 menunjukkan salah, dan nilai 1 menunjukkan benar dan masih ada nilai-nilai yang terletak antara benar dan salah.

Secara matematis suatu himpunan fuzzy $A$ dalam semesta pembicaraan $X$ dapat dinyatakan sebagai himpunan pasangan terurut

$$
A=\left\{\left(x \mid \mu_{A}(x)\right) \mid x \in X\right\}
$$

dimana $\mu_{A}$ adalah fungsi keanggotaan dari himpunan fuzzy $A$, yang merupakan suatu 
pemetaan dari himpunan semesta $X$ ke selang tertutup $[0,1]$ (Susilo, 2006).

Apabila semesta $X$ adalah himpunan yang kontinu, maka himpunan fuzzy $A$ dinyatakan dengan

$$
A=\int_{x \in X} x \mid \mu_{A}(x)
$$

Dimana lambang $\int$ di sini bukan lambang integral seperti yang dikenal dalam kalkulus, tetapi melambangkan keseluruhan unsur-unsur $x \in X$ bersama dengan derajat keanggotaannya dalam himpunan fuzzy $A$. Apabila semesta $X$ adalah himpunan yang diskrit, maka himpunan fuzzy $A$ dinyatakan dengan

$$
A=\sum_{x \in X} x \mid \mu_{A}(x)
$$

Dimana lambang $\Sigma$ di sini tidak melambangkan operasi penjumlahan seperti yang dikenal dalam aritmatika, tetapi melambangkan keseluruhan unsur-unsur $x \in X$ bersama dengan derajat keanggotaannya dalam himpunan fuzzy $A$.

Terdapat tiga oprasi dasar pada himpunan fuzzy,yaitu operasi irisan (Intersection), operasi Gabungan (union), dan operasi tidak (complement).

Operasi irisan berhubungan dengan operasi interseksi pada himpunan tegas. $\alpha$ predikat sebagai hasil operasi dengan operator "Dan" diperoleh dengan mengambil nilai keanggotaan terkecil antar element pada himpunan-himpunan yang bersangkutan. Ditunjukkan sebagai $A \cap B$ adalah suatu fuzzy subset $C$ dari $U$ sehingga $C=A \cap B$ dan derajat keanggotaannya

$$
\mu_{A \cap B}=\min \left(\mu_{A}[x], \mu_{B}[y]\right)
$$

Operasi gabungan berhubungan dengan operasi union pada himpunan tegas. $\alpha$-predikat sebagai hasil operasi dengan operator "Atau" diperoleh dengan mengambil nilai keanggotaan terbesar antar element pada himpunanhimpunan yang bersangkutan. Ditunjukkan sebagai $A \cup B$ adalah suatu fuzzy subset $D$ dari $U$ sehingga $D=A \cup B$ dan derajat keanggotaannya

$$
\mu_{A \cup B}=\operatorname{maks}\left(\mu_{A}[x], \mu_{B}[y]\right)
$$

Operasi tidak berhubungan dengan operasi komplemen pada himpunan tegas. $\alpha$ predikat sebagai hasil operasi dengan operator "Tidak" diperoleh dengan mengurangkan nilai keanggotaan elemen pada himpunan yang bersangkutan dari 1. Ditunjukkan sebagai A' (a komplemen) dan derajat keanggotaannya

$$
\mu_{A}=1-\mu_{A}
$$

\section{Relasi Fuzzy}

Relasi fuzzy $\tilde{R}$ antara elemen-elemen dalam himpunan $X$ dengan elemen-elemen dalam himpunan $Y$ didefinisikan sebagai himpunan bagian fuzzy dari perkalian cartesius $X \times Y$, yaitu himpunan fuzzy

$$
\tilde{R}=\left\{\left((x, y) \mid \mu_{R}(x, y)\right) \mid(x, y) \in X \times Y\right\}
$$

Relasi fuzzy $\tilde{R}$ disebut juga relasi fuzzy pada himpunan (semesta) $X \times Y$. Jika $X=Y$, maka $\tilde{R}$ disebut relasi fuzzy pada himpunan $X$.

Relasi tegas hanya menyatakan adanya atau tidak adanya hubungan antara elemenelemen dari suatu himpunan dengan elemenelemen dari himpunan lainnya, sedangkan relasi fuzzy lebih luas dari itu, karena juga menyatakan derajat keeratan hubungan relasi tersebut.

\section{PEMBAHASAN}

\section{A. Geometri Fuzzy}

Proyeksi geometri fuzzy merupakan pengembangan dari proyeksi geometri tegas dengan himpunan fuzzy yang didefinisikan sebagai berikut:

Misal $P\left(x_{P}, y_{P}, z_{P}\right)$ merupakan suatu titik di koordinat ruang $\left(R^{3}\right), \tilde{P}=\left\{P \mid \mu_{\tilde{P}}\right\}$ himpunan fuzzy di $P$, jadi $\tilde{P}=\left\{x_{P}, y_{P}, z_{P} \mid \mu_{\tilde{P}}\right\}$ dinamakan titik fuzzy, misal

$$
g\left\{\begin{array}{l}
\left(A_{1} x+B_{1} y+C_{1} z=D\right) \\
\left(A_{2} x+B_{2} y+C_{2} z=D\right)
\end{array}\right.
$$

merupakan suatu persamaan garis di koordinat ruang $\left(R^{3}\right), \tilde{g}=\left\{g \mid \mu_{\tilde{g}}\right\}$ himpunan fuzzy di $g$, jadi

$$
\tilde{g}=\left\{\begin{array}{l}
\left(A_{1} x+B_{1} y+C_{1} z=D\right) \\
\left(A_{2} x+B_{2} y+C_{2} z=D\right)
\end{array} \mid \mu_{\tilde{g}}\right\}
$$

dinamakan garis fuzzy, dan misal $V \equiv A x+B y+$ $C z=D$ merupakan persamaan bidang dikoordinat ruang $\left(R^{3}\right), \tilde{V}=\left\{V \mid \mu_{\tilde{V}}\right\}$ himpunan fuzzy di $V$, jadi $\tilde{V}=\left\{A x+B y+C z=D \mid \mu_{\widetilde{V}}\right\}$ dinamakan bidang fuzzy.

\section{B. Proyeksi Geometri Fuzzy}

\section{Proyeksi Titik Fuzzy pada Garis Fuzzy}

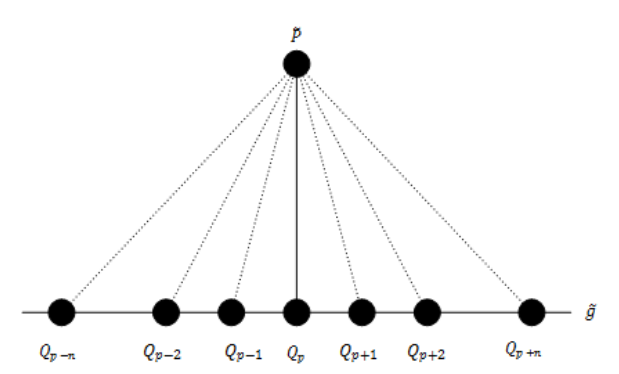

Gambar 6. Proyeksi Titik Fuzzy pada Garis Fuzzy 
Misal sebuah titik fuzzy $\tilde{P}\left(x_{p}, y_{p}, z_{p} \mid \mu_{\tilde{p}}\right)$ diproyeksikan terhadap garis fuzzy

$$
\tilde{g} \equiv\left(\left\{\begin{array}{l}
\left(A_{1} x+B_{1} y+C_{1} z+D=0\right) \\
\left(A_{2} x+B_{2} y+C_{2} z+D=0\right)
\end{array} \mid \mu_{\tilde{g}}\right),\right.
$$

untuk mengetahui hasil proyeksinya, dapat dicari dengan langkah-langkah sebagai berikut:

Pertama, Diberikan titik fuzzy $\tilde{P}\left(x_{p}, y_{p}, z_{p} \mid \mu_{\tilde{p}}\right) \quad$ sebagai unsur yang diproyeksikan dan garis fuzzy

$$
\tilde{g} \equiv\left(\left\{\begin{array}{l}
\left(A_{1} x+B_{1} y+C_{1} z+D=0\right) \\
\left(A_{2} x+B_{2} y+C_{2} z+D=0\right)
\end{array} \mid \mu_{\tilde{g}}\right)\right.
$$

sebagai unsur proyektor.

Kedua, dicari koordinat hasil proyeksi tegas titik fuzzy $\tilde{P}\left(x_{p}, y_{p}, z_{p} \mid \mu_{\tilde{P}}\right)$ terhadap garis fuzzy

$$
\tilde{g} \equiv\left(\left\{\begin{array}{l}
\left(A_{1} x+B_{1} y+C_{1} z+D=0\right) \\
\left(A_{2} x+B_{2} y+C_{2} z+D=0\right)
\end{array} \mid \mu_{\tilde{g}}\right),\right.
$$

yang didefinisikan dengan $\tilde{Q}_{p}$ pada garis $\tilde{g}$. Selanjutnya mencari jarak antara titik $\tilde{P}$ dengan titik $\tilde{Q}_{p}$, setelah itu mencari jarak antara titik fuzzy $\widetilde{P}$ dengan titik fuzzy $\tilde{Q}_{i}$ (titik-titik fuzzy pada garis fuzzy $\left.\tilde{g}, \tilde{Q}_{i} \in \tilde{g}\right)$.

Ketiga, dicari derajat keanggotaan relasi antara titik fuzzy $\tilde{P}$ dengan garis fuzzy $\tilde{g}$ yang didefinisikan dengan $\left(\mu_{\tilde{R}}\right)$, dimana $\tilde{R}$ merupakan relasi dari titik fuzzy $\tilde{P}$ pada garis fuzzy $\tilde{g}$, $(\tilde{R} \subset \tilde{P} \times \tilde{g})$.

$$
\tilde{R}=\left[\left\{\left(\tilde{P}, \tilde{Q}_{i}\right) \mid \mu_{\tilde{R}}\left(\tilde{P}, \tilde{Q}_{i}\right)\right\} \mid\left(\tilde{P}, \tilde{Q}_{i}\right) \in \tilde{P} \times \tilde{g}\right]
$$

Pada proyeksi geometri fuzzy dari titik fuzzy ke garis fuzzy, hasil proyeksi tidak hanya berupa satu titik fuzzy seperti pada proyeksi geometri tegas, akan tetapi semua titik fuzzy pada garis fuzzy proyektor dengan derajat keanggotaan ketebalan yang dipengaruhi oleh derajat keanggotaan global relasi fuzzy.

Derajat keanggotaan relasi $\left(\mu_{\tilde{R}}\right)$ bisa diketahui dengan fungsi berikut:

$$
\mu_{\tilde{R}}\left(\tilde{P}, \tilde{Q}_{i}\right)=e^{-\left(w_{i}-v\right)^{0,5}}
$$

dimana

$$
v=\text { Jarak terdekat titik fuzzy } \tilde{P} \text { pada } \tilde{Q}_{p}
$$

$w_{i}=$ Jarak titik fuzzy $\tilde{P}$ pada $\tilde{Q}_{i}$

Derajat keanggotaan relasi tersebut merupakan representasi dari seberapa besar atau kuat relasi antara titik fuzzy $\tilde{P}$ dengan garis fuzzy $\tilde{g}$, dengan berasumsi jika jarak antara titik fuzzy $\tilde{P}$ dengan $\tilde{Q}_{i} \in \tilde{g}$ semakin dekat, maka kekuatan $\mu_{\tilde{R}}$ semakin besar. Sedangkan jika jarak antara titik fuzzy $\tilde{P}$ dengan $\tilde{Q}_{i}$ semakin jauh maka berlaku sebaliknya. Akan tetapi, kekuatan relasi tersebut masih berada dalam interval $[0,1]$.

Relasi tersebut dapat digambar ke dalam tabel berikut.
Tabel 1. Tabel Matrik Relasi Titik fuzzy $\widetilde{P}$ dengan Garis fuzzy $\tilde{g},\left(\mu_{\tilde{R}}\left(\tilde{P}, \tilde{Q}_{i}\right)\right)$

\begin{tabular}{ccccc}
\hline$\tilde{R}$ & $\tilde{Q}_{p-n}$ & $\ldots$ & $\tilde{Q}_{p-1}$ & $\tilde{Q}_{p}$ \\
\hline$\tilde{P}$ & $\mu_{\tilde{R}}\left(\tilde{P}, \tilde{Q}_{p-n}\right)$ & $\ldots$ & $\mu_{\tilde{R}}\left(\tilde{P}, \tilde{Q}_{p-1}\right)$ & $\mu_{\tilde{R}}\left(\tilde{P}, \tilde{Q}_{p}\right)$ \\
\hline & & & \\
\hline$\tilde{R}$ & $\tilde{Q}_{p+1}$ & $\ldots$ & $\tilde{Q}_{p+n}$ \\
\hline & $\tilde{P}$ & $\mu_{\tilde{R}}\left(\tilde{P}, \tilde{Q}_{p+1}\right)$ & $\ldots$ & $\mu_{\tilde{R}}\left(\tilde{P}, \tilde{Q}_{p+n}\right)$ \\
\hline
\end{tabular}

Sumber: Djauhari, 1990:55

Sehingga diperoleh derajat keanggotaan relasi titik $\widetilde{P}$ dengan garis $\tilde{g} \mu_{\tilde{R}}\left(\widetilde{P}, \widetilde{Q}_{i}\right)$ sebagai berikut

$$
\begin{aligned}
\mu_{\tilde{R}}\left(\tilde{P}, \tilde{Q}_{i}\right)= & \left\{\left(\left(\tilde{P}, \tilde{Q}_{p-n}\right) \mid \mu_{\widetilde{R}}\left(\tilde{P}, \tilde{Q}_{p-n}\right)\right), \ldots,\right. \\
& \left(\left(\tilde{P}, \tilde{Q}_{p-1}\right) \mid \mu_{\tilde{R}}\left(\tilde{P}, \tilde{Q}_{p-1}\right)\right), \\
& \left(\left(\tilde{P}, \tilde{Q}_{p}\right) \mid \mu_{\tilde{R}}\left(\tilde{P}, \tilde{Q}_{p}\right)\right) \\
& \left(\left(\tilde{P}, \tilde{Q}_{p+1}\right) \mid \mu_{\tilde{R}}\left(\tilde{P}, \tilde{Q}_{p+1}\right)\right), \ldots, \\
& \left.\left(\left(\tilde{P}, \tilde{Q}_{p+n}\right) \mid \mu_{\tilde{R}}\left(\tilde{P}, \tilde{Q}_{p+n}\right)\right)\right\}
\end{aligned}
$$

Keempat, setelah diketahui $\mu_{\tilde{R}}\left(\tilde{P}, \widetilde{Q}_{i}\right)$, dicari hasil perkalian derajat keanggotaan ketebalan titik yang diproyeksikan $\mu_{\tilde{P}}$ dan derajat keanggotaan relasi $\mu_{\tilde{R}}\left(\tilde{P}, \tilde{Q}_{i}\right)$, yang didefinisikan dengan $\mu_{k}\left(\tilde{P}, \tilde{Q}_{i}\right)$. Selanjutnya mencari derajat keanggotaan ketebalan masing-masing titik hasil proyeksi $\left(\mu_{\widetilde{P \prime}}\left(\widetilde{P}, \widetilde{Q}_{i}\right)\right)$, yang merupakan irisan (intersection) dari $\mu_{k}\left(\widetilde{P}, \widetilde{Q}_{i}\right)$ dengan $\mu_{\tilde{g}}$.

$$
\begin{array}{ll}
\mu_{\widetilde{P^{\prime}}}\left(\tilde{P}, \tilde{Q}_{p-n}\right) & =\min \left(\mu_{k}\left(\tilde{P}, \tilde{Q}_{p-n}\right), \mu_{\tilde{g}}\right) \\
\vdots & \\
\mu_{\widetilde{P^{\prime}}}\left(\tilde{P}, \tilde{Q}_{p-1}\right) & =\min \left(\mu_{k}\left(\tilde{P}, \tilde{Q}_{p-1}\right), \mu_{\tilde{g}}\right) \\
\mu_{\widetilde{P^{\prime}}}\left(\tilde{P}, \tilde{Q}_{p}\right) & =\min \left(\mu_{k}\left(\tilde{P}, \tilde{Q}_{p}\right), \mu_{\tilde{g}}\right) \\
\mu_{\widetilde{P^{\prime}}}\left(\tilde{P}, \tilde{Q}_{p+1}\right) & =\min \left(\mu_{k}\left(\widetilde{P}, \tilde{Q}_{p+1}\right), \mu_{\tilde{g}}\right) \\
\quad \vdots & \\
\mu_{\widetilde{P^{\prime}}}\left(\tilde{P}, \tilde{Q}_{p+n}\right) & =\min \left(\mu_{k}\left(\widetilde{P}, \tilde{Q}_{p+n}\right), \mu_{\tilde{g}}\right)
\end{array}
$$

Jadi didapatkan hasil proyeksi yaitu berupa garis fuzzy $\widetilde{P}^{\prime}=$ $\left\{\begin{array}{l}\left(A_{1} x+B_{1} y+C_{1} z+D=0\right) \\ \left(A_{2} x+B_{2} y+C_{2} z+D=0\right)\end{array} \mid \mu_{\widetilde{P \prime}}\right.$, dengan koordinat yang sama dengan garis proyektor $\tilde{g}$ karena $\widetilde{P^{\prime}} \in \tilde{g}$, dan dengan $\mu_{\widetilde{P^{\prime}}}$ sebagai berikut:

$$
\begin{aligned}
& \mu_{\widetilde{P^{\prime}}}\left(\tilde{P}, \tilde{Q}_{i}\right)=\left\{\left(\left(\tilde{P}, \tilde{Q}_{p-n}\right) \mid \mu_{\widetilde{P^{\prime}}}\left(\tilde{P}, \tilde{Q}_{p-n}\right)\right), \ldots,\right. \\
& \left(\left(\tilde{P}, \tilde{Q}_{p-1}\right) \mid \mu_{P^{\prime}}\left(\tilde{P}, \tilde{Q}_{p-1}\right)\right), \\
& \left(\left(\tilde{P}, \tilde{Q}_{p}\right) \mid \mu_{\widetilde{P}}\left(\tilde{P}, \tilde{Q}_{p}\right)\right), \\
& \left(\left(\widetilde{P}, \widetilde{Q}_{p+1}\right) \mid \mu_{\widetilde{P}^{\prime}}\left(\tilde{P}, \widetilde{Q}_{p+1}\right)\right), \ldots, \\
& \left.\left(\left(\tilde{P}, \tilde{Q}_{p+n}\right) \mid \mu_{\widetilde{P}^{\prime}}\left(\widetilde{P}, \tilde{Q}_{p+n}\right)\right)\right\}
\end{aligned}
$$




\section{Proyeksi Titik Fuzzy pada Bidang Fuzzy}

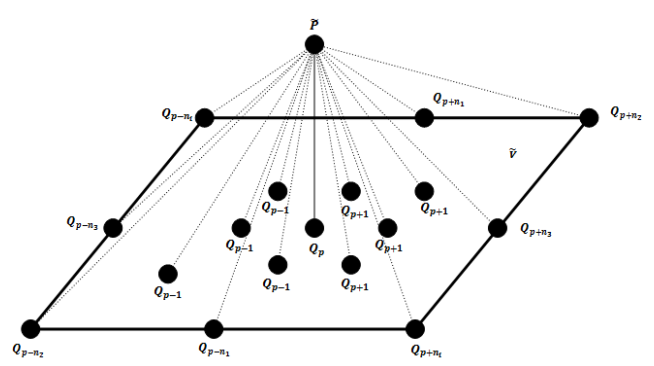

Gambar 7. Proyeksi Titik Fuzzy pada Bidang Fuzzy

Misal sebuah titik fuzzy $\tilde{P}\left(x_{p}, y_{p}, z_{p} \mid \mu_{\tilde{p}}\right)$ diproyeksikan terhadap bidang fuzzy $\tilde{V}=\left\{A x+B y+C z=D \mid \mu_{\tilde{V}}\right\}$, untuk mengetahui hasil proyeksinya, dapat dicari dengan langkahlangkah sebagai berikut:

Pertama, Diberikan titik fuzzy $\tilde{P}\left(x_{p}, y_{p}, z_{p} \mid \mu_{\tilde{p}}\right) \quad$ sebagai $\quad$ unsur $\quad$ yang diproyeksikan dan bidang fuzzy $\tilde{V}=\{A x+B y+$ $\left.C z=D \mid \mu_{\tilde{V}}\right\}$, sebagai unsur proyektor.

Kedua, dicari koordinat hasil proyeksi tegas titik fuzzy $\tilde{P}\left(x_{p}, y_{p}, z_{p} \mid \mu_{\tilde{P}}\right)$ terhadap bidang fuzzy $\tilde{V}=\left\{A x+B y+C z=D \mid \mu_{\tilde{V}}\right\}$, yang didefinisikan dengan $\tilde{Q}_{p}$ pada bidang $\tilde{V}$. Selanjutnya mencari jarak antara titik $\tilde{P}$ dengan titik $\tilde{Q}_{p}$, setelah itu mencari jarak antara titik fuzzy $\tilde{P}$ dengan titik fuzzy $\tilde{Q}_{i}$ (titik-titik fuzzy pada garis fuzzy $\left.\tilde{V}, \tilde{Q}_{i} \in \tilde{V}\right)$.

Ketiga, dicari derajat keanggotaan relasi antara titik fuzzy $\tilde{P}$ dengan bidang fuzzy $\tilde{V}$ yang didefinisikan dengan $\left(\mu_{\tilde{R}}\right)$, dimana $\tilde{R}$ merupakan relasi dari titik fuzzy $\tilde{P}$ pada bidang fuzzy $\tilde{V}$, $(\tilde{R} \subset \tilde{P} \times \tilde{V})$.

$$
\tilde{R}=\left[\left\{\left(\tilde{P}, \tilde{Q}_{i}\right) \mid \mu_{\tilde{R}}\left(\tilde{P}, \tilde{Q}_{i}\right)\right\} \mid\left(\tilde{P}, \tilde{Q}_{i}\right) \in \tilde{P} \times \tilde{V}\right]
$$

Pada proyeksi geometri fuzzy dari titik fuzzy ke bidang fuzzy, hasil proyeksi tidak hanya berupa satu titik fuzzy seperti pada proyeksi geometri tegas, akan tetapi semua titik fuzzy pada bidang fuzzy proyektor dengan derajat keanggotaan ketebalan yang dipengaruhi oleh derajat keanggotaan global relasi fuzzy.

Derajat keanggotaan relasi $\left(\mu_{\tilde{R}}\right)$ bisa diketahui dengan fungsi berikut:

$$
\mu_{\tilde{R}}\left(\tilde{P}, \tilde{Q}_{i}\right)=e^{-\left(w_{i}-v\right)^{0,5}}
$$

dimana

$$
\begin{aligned}
& v=\text { Jarak terdekat titik fuzzy } \tilde{P} \text { pada } \tilde{Q}_{p} \\
& w_{i}=\text { Jarak titik fuzzy } \tilde{P} \text { pada } \tilde{Q}_{i}
\end{aligned}
$$

Derajat keanggotaan relasi tersebut merupakan representasi dari seberapa besar atau kuat relasi antara titik fuzzy $\tilde{P}$ dengan bidang fuzzy $\tilde{V}$, dengan berasumsi jika jarak antara titik fuzzy $\tilde{P}$ dengan $\tilde{Q}_{i} \in \tilde{V}$ semakin dekat, maka kekuatan $\mu_{\tilde{R}}$ semakin besar. Sedangkan jika jarak antara titik fuzzy $\tilde{P}$ dengan $\tilde{Q}_{i}$ semakin jauh maka berlaku sebaliknya. Akan tetapi, kekuatan relasi tersebut masih berada dalam interval $[0,1]$.

Relasi tersebut dapat digambar ke dalam tabel berikut

Tabel 2. Tabel Matrik Relasi Titik fuzzy $\widetilde{P}$ dengan Bidang fuzzy $\tilde{V},\left(\mu_{\tilde{R}}\left(\widetilde{P}, \tilde{Q}_{i}\right)\right)$

\begin{tabular}{ccccc}
\hline$\tilde{R}$ & $\tilde{Q}_{p-n_{n}}$ & $\ldots$ & $\tilde{Q}_{p-1_{n}}$ & $\tilde{Q}_{p}$ \\
\hline$\tilde{P}$ & $\mu_{\tilde{R}}\left(\tilde{P}, \tilde{Q}_{p-n_{n}}\right)$ & $\ldots$ & $\mu_{\tilde{R}}\left(\tilde{P}, \tilde{Q}_{p-1_{n}}\right)$ & $\mu_{\tilde{R}}\left(\tilde{P}, \tilde{Q}_{p}\right)$ \\
\hline & & & \\
\hline$\tilde{R}$ & $\tilde{Q}_{p+1_{n}}$ & $\ldots$ & $\tilde{Q}_{p+n_{n}}$ \\
\hline$\tilde{P}$ & $\mu_{\tilde{R}}\left(\tilde{P}, \tilde{Q}_{p+1_{n}}\right)$ & $\ldots$ & $\mu_{\tilde{R}}\left(\tilde{P}, \tilde{Q}_{p+n_{n}}\right)$ \\
\hline
\end{tabular}

\section{Sumber: Djauhari, 1990:55}

Sehingga diperoleh derajat keanggotaan relasi titik $\widetilde{P}$ dengan bidang $\tilde{V} \mu_{\tilde{R}}\left(\tilde{P}, \tilde{Q}_{i}\right)$ sebagai berikut

$$
\begin{aligned}
\mu_{\tilde{R}}\left(\tilde{P}, \tilde{Q}_{i}\right)= & \left\{\left(\left(\tilde{P}, \tilde{Q}_{p-n_{n}}\right) \mid \mu_{\widetilde{R}}\left(\widetilde{P}, \tilde{Q}_{p-n_{n}}\right)\right), \ldots,\right. \\
& \left.\left(\left(\tilde{P}, \tilde{Q}_{p-1_{n}}\right) \mid \mu_{\tilde{R}} \tilde{P}, \tilde{Q}_{p-1_{n}}\right)\right), \\
& \left(\left(\tilde{P}, \tilde{Q}_{p}\right) \mid \mu_{\tilde{R}}\left(\tilde{P}, \tilde{Q}_{p}\right)\right) \\
& \left(\left(\tilde{P}, \tilde{Q}_{p+1_{n}}\right) \mid \mu_{\tilde{R}}\left(\tilde{P}, \tilde{Q}_{p+1_{n}}\right)\right), \ldots, \\
& \left.\left(\left(\tilde{P}, \tilde{Q}_{p+n_{n}}\right) \mid \mu_{\tilde{R}}\left(\tilde{P}, \tilde{Q}_{p+n_{n}}\right)\right)\right\}
\end{aligned}
$$

Keempat, setelah diketahui $\mu_{\tilde{R}}\left(\tilde{P}, \tilde{Q}_{i}\right)$, dicari hasil perkalian derajat keanggotaan ketebalan titik yang diproyeksikan $\mu_{\tilde{P}}$ dan derajat keanggotaan relasi $\mu_{\tilde{R}}\left(\tilde{P}, \tilde{Q}_{i}\right)$, yang didefinisikan dengan $\mu_{k}\left(\tilde{P}, \tilde{Q}_{i}\right)$. Selanjutnya mencari derajat keanggotaan ketebalan masing-masing titik hasil proyeksi $\left(\mu_{\widetilde{P \prime}}\left(\widetilde{P}, \widetilde{Q}_{i}\right)\right)$, yang merupakan irisan (intersection) dari $\mu_{k}\left(\widetilde{P}, \widetilde{Q}_{i}\right)$ dengan $\mu_{\widetilde{V}}$.

$$
\begin{gathered}
\mu_{\widetilde{P^{\prime}}}\left(\tilde{P}, \tilde{Q}_{p-n_{n}}\right)=\min \left(\mu_{k}\left(\tilde{P}, \tilde{Q}_{p-n_{n}}\right), \mu_{\tilde{g}}\right) \\
\vdots \\
\mu_{\widetilde{P^{\prime}}}\left(\tilde{P}, \tilde{Q}_{p-1_{n}}\right)=\min \left(\mu_{k}\left(\tilde{P}, \tilde{Q}_{p-1_{n}}\right), \mu_{\tilde{g}}\right) \\
\mu_{\widetilde{P}^{\prime}}\left(\tilde{P}, \widetilde{Q}_{p}\right)=\min \left(\mu_{k}\left(\tilde{P}, \widetilde{Q_{p}}\right), \mu_{\tilde{g}}\right) \\
\mu_{\widetilde{P^{\prime}}}\left(\tilde{P}, \tilde{Q}_{p+1_{n}}\right)=\min \left(\mu_{k}\left(\tilde{P}, \tilde{Q}_{p+1_{n}}\right), \mu_{\tilde{g}}\right) \\
\vdots \\
\mu_{\widetilde{P^{\prime}}}\left(\tilde{P}, \tilde{Q}_{p+n_{n}}\right)=\min \left(\mu_{k}\left(\tilde{P}, \tilde{Q}_{p+n_{n}}\right), \mu_{\tilde{g}}\right)
\end{gathered}
$$

Jadi didapatkan hasil proyeksi berupa bidang fuzzy $\widetilde{P^{\prime}}=\left\{A x+B y+C z=D \mid \mu_{\widetilde{P}}\right\}$, dengan koordinat yang sama dengan bidang proyektor $\tilde{V}$ karena $\widetilde{P}^{\prime} \in \tilde{V}$, dan dengan $\mu_{\widetilde{P^{\prime}}}$ sebagai berikut:

$$
\begin{aligned}
\mu_{\widetilde{P^{\prime}}}\left(\tilde{P}, \tilde{Q}_{i}\right)= & \left\{\left(\left(\tilde{P}, \tilde{Q}_{p-n_{n}}\right) \mid \mu_{\widetilde{P^{\prime}}}\left(\tilde{P}, \tilde{Q}_{p-n_{n}}\right)\right), \ldots,\right. \\
& \left(\left(\tilde{P}, \tilde{Q}_{p-1_{n}}\right) \mid \mu_{\widetilde{P^{\prime}}}\left(\tilde{P}, \tilde{Q}_{p-1_{n}}\right)\right),
\end{aligned}
$$




$$
\begin{aligned}
& \left(\left(\tilde{P}, \tilde{Q}_{p}\right) \mid \mu_{\widetilde{P^{\prime}}}\left(\tilde{P}, \tilde{Q}_{p}\right)\right), \\
& \left(\left(\tilde{P}, \tilde{Q}_{p+1_{n}}\right) \mid \mu_{\widetilde{P^{\prime}}}\left(\tilde{P}, \tilde{Q}_{p+1_{n}}\right)\right), \ldots, \\
& \left.\left(\left(\tilde{P}, \tilde{Q}_{p+n_{n}}\right) \mid \mu_{\widetilde{P^{\prime}}}\left(\tilde{P}, \tilde{Q}_{p+n_{n}}\right)\right)\right\}
\end{aligned}
$$

\section{Proyeksi Garis Fuzzy pada Bidang Fuzzy}

Pada proyeksi geometri fuzzy pada garis fuzzy pada bidang fuzzy, sama halnya pada proyeksi geometri tegas yaitu terdapat tiga bentuk proyeksi diantaranya garis fuzzy yang diproyeksikan tegak lurus dengan bidang fuzzy proyektor, garis fuzzy yang diproyeksikan sejajar dengan bidang fuzzy proyektor, dan garis fuzzy yang diproyeksikan tidak sejajar dan tidak saling tegak lurus dengan bidang fuzzy proyektor.

\section{a. Proyeksi Garis Fuzzy $\widetilde{g}$ pada Bidang Fuzzy $\widetilde{V}$ Jika Garis $\widetilde{g}$ Saling Tegak Lurus dengan Bidang $\widetilde{V}$}

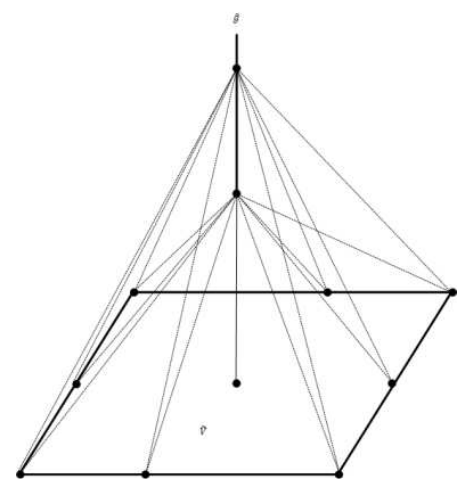

Gambar 8. Proyeksi Garis Fuzzy g̃ pada Bidang Fuzzy $\tilde{V}$ yang Saling Tegak Lurus

Misal sebuah garis fuzzy $\tilde{g}$ diproyeksikan terhadap bidang fuzzy $\tilde{V}$, untuk mengetahui hasil proyeksinya, dapat dicari dengan langkahlangkah sebagai berikut:

Pertama, diberikan garis fuzzy $\tilde{g}$ sebagai unsur yang diproyeksikan dan bidang fuzzy $\tilde{V}$, sebagai unsur proyektor.

Kedua, dicari koordinat hasil proyeksi tegas garis fuzzy $\tilde{g}$ terhadap bidang fuzzy $\tilde{V}$, yang di-definisikan dengan $\tilde{Q}_{p}$ pada bidang $\tilde{V}$. Selanjutnya mencari jarak antara titik $\tilde{g}_{p}$ yang mana titik $\tilde{g}_{p} \in \tilde{g}$ dan $\tilde{g}_{p}$ merupakan titik dengan jarak terdekat dengan titik $\tilde{Q}_{p}$, setelah itu mencari jarak antara titik $\tilde{g}_{i} \in \tilde{g}$ dengan titik fuzzy $\tilde{Q}_{i}$ (titik-titik fuzzy pada bidang fuzzy $\tilde{V}$, $\left.\tilde{Q}_{i} \in \tilde{V}\right)$.

Ketiga, dicari derajat keanggotaan relasi antara titik $\widetilde{g}_{\imath} \in \tilde{g}$ dengan bidang fuzzy $\tilde{V}$ yang didefinisikan dengan $\left(\mu_{\tilde{R}}\right)$, dimana $\widetilde{R}$ merupakan relasi dari titik-titik fuzzy pada $\tilde{g}$ terhadap bidang fuzzy $\tilde{V},(\tilde{R} \subset \tilde{g} \times \tilde{V})$.

$$
\tilde{R}=\left[\left\{\left(\tilde{g}_{i}, \tilde{Q}_{i}\right) \mid \mu_{\tilde{R}}\left(\tilde{g}_{i}, \tilde{Q}_{i}\right)\right\} \mid\left(\tilde{g}_{i}, \tilde{Q}_{i}\right) \in \tilde{g} \times \tilde{V}\right]
$$

Pada proyeksi geometri fuzzy dari garis fuzzy pada bidang fuzzy, hasil proyeksi tidak hanya berupa satu titik fuzzy seperti pada proyeksi geometri tegas, akan tetapi semua titik fuzzy pada bidang fuzzy proyektor dengan derajat keanggotaan ketebalan yang dipengaruhi oleh derajat keanggotaan global relasi fuzzy.

Derajat keanggotaan relasi $\left(\mu_{\tilde{R}}\right)$ bisa diketahui dengan fungsi berikut:

dimana

$$
\mu_{\tilde{R}}\left(\tilde{P}, \tilde{Q}_{i}\right)=e^{-\left(w_{i}-v\right)^{0,5}}
$$

$$
v=\text { Jarak terdekat garis } \tilde{g} \text { pada bidang } \tilde{V}
$$$$
w_{i}=\text { Jarak titik } \tilde{g} \text { dengan } \tilde{Q}_{i}
$$

Derajat keanggotaan relasi tersebut merupakan representasi dari seberapa besar atau kuat relasi antara titik fuzzy $\tilde{g}_{i}$ dengan bidang fuzzy $\tilde{V}$, dengan berasumsi jika jarak antara titik fuzzy $\tilde{g}_{i}$ dengan $\tilde{Q}_{i} \in \tilde{V}$ semakin dekat, maka kekuatan $\mu_{\tilde{R}}$ semakin besar. Sedangkan jika jarak antara titik fuzzy $\tilde{g}_{i}$ dengan $\tilde{Q}_{i}$ semakin juah, maka berlaku sebaliknya yaitu kekuatan $\mu_{\tilde{R}}$ semakin kecil, akan tetapi kekuatan masing-masing relasi tersebut masih berada pada interval $[0,1]$.

Relasi tersebut dapat digambar ke dalam tabel berikut

Tabel 3. Tabel Matriks Relasi Garis Fuzzy $\tilde{g}$ dengan Bidang Fuzzy $\tilde{V}, \quad \tilde{g}$ Tegak Lurus $\tilde{V}$, $\left(\mu_{\tilde{R}}\left(\tilde{g}_{i}, \widetilde{Q}_{i}\right)\right)$

\begin{tabular}{ccccc}
\hline$\tilde{R}$ & $\tilde{Q}_{p-n_{i}}$ & $\cdots$ & $\tilde{Q}_{p-1}$ & $\tilde{Q}_{p}$ \\
\hline$\tilde{g}_{1}$ & $\mu_{\tilde{R}}\left(\tilde{g}_{1}, \tilde{Q}_{p-n_{i}}\right)$ & $\cdots$ & $\mu_{\tilde{R}}\left(\tilde{g}_{1}, \tilde{Q}_{p-1}\right)$ & $\mu_{\tilde{R}}\left(\tilde{g}_{1}, \tilde{Q}_{p}\right)$ \\
\hline$\tilde{g}_{2}$ & $\mu_{\tilde{R}}\left(\tilde{g}_{2}, \tilde{Q}_{p-n_{i}}\right)$ & $\ldots$ & $\mu_{\tilde{R}}\left(\tilde{g}_{2}, \tilde{Q}_{p-1}\right)$ & $\mu_{\tilde{R}}\left(\tilde{g}_{2}, \tilde{Q}_{p}\right)$ \\
\hline$\tilde{g}_{3}$ & $\mu_{\tilde{R}}\left(\tilde{g}_{3}, \tilde{Q}_{p-n_{i}}\right)$ & $\ldots$ & $\mu_{\tilde{R}}\left(\tilde{g}_{3}, \tilde{Q}_{p-1}\right)$ & $\mu_{\tilde{R}}\left(\tilde{g}_{3}, \tilde{Q}_{p}\right)$ \\
\hline$\vdots$ & $\vdots$ & & $\vdots$ & $\vdots$ \\
\hline$\tilde{g}_{n}$ & $\mu_{\tilde{R}}\left(\tilde{g}_{n}, \tilde{Q}_{p-n_{i}}\right)$ & $\ldots$ & $\mu_{\tilde{R}}\left(\tilde{g}_{n}, \tilde{Q}_{p-1}\right)$ & $\mu_{\tilde{R}}\left(\tilde{g}_{n}, \tilde{Q}_{p}\right)$ \\
\hline
\end{tabular}

\begin{tabular}{cccc}
\hline$\tilde{R}$ & $\tilde{Q}_{p+1}$ & $\cdots$ & $\tilde{Q}_{p-n_{i}}$ \\
\hline$\tilde{g}_{1}$ & $\mu_{\tilde{R}}\left(\tilde{g}_{1}, \tilde{Q}_{p+1}\right)$ & $\cdots$ & $\mu_{\tilde{R}}\left(\tilde{g}_{1}, \tilde{Q}_{p-n_{i}}\right)$ \\
\hline$\tilde{g}_{2}$ & $\mu_{\tilde{R}}\left(\tilde{g}_{2}, \tilde{Q}_{p+1}\right)$ & $\cdots$ & $\mu_{\tilde{R}}\left(\tilde{g}_{2}, \tilde{Q}_{p-n_{i}}\right)$ \\
\hline$\tilde{g}_{3}$ & $\mu_{\tilde{R}}\left(\tilde{g}_{3}, \tilde{Q}_{p+1}\right)$ & $\cdots$ & $\mu_{\tilde{R}}\left(\tilde{g}_{3}, Q_{p-n_{i}}\right)$ \\
\hline$\vdots$ & $\vdots$ & & $\vdots$ \\
\hline$\tilde{g}_{n}$ & $\mu_{\tilde{R}}\left(\tilde{g}_{n}, \tilde{Q}_{p+1}\right)$ & $\cdots$ & $\mu_{\tilde{R}}\left(g_{n}, \tilde{Q}_{p-n_{i}}\right)$ \\
\hline
\end{tabular}

Sumber: Djauhari, 1990:55

Sehingga diperoleh derajat keanggotaan relasi garis fuzzy $\tilde{g}$ pada bidang fuzzy $\tilde{V}$ dengan $\mu_{\tilde{R}}\left(\tilde{g}, \tilde{Q}_{i}\right)$ sebagai berikut:

$$
\begin{aligned}
\mu_{\tilde{R}}\left(\tilde{g}, \tilde{Q}_{i}\right)= & \left\{\left(\left(\tilde{g}, \tilde{Q}_{p-n_{i}}\right) \mid \mu_{\tilde{R}}\left(\tilde{g}, \tilde{Q}_{p-n_{i}}\right)\right), \ldots,\right. \\
& \left(\left(\tilde{g}, \tilde{Q}_{p-1}\right) \mid \mu_{\tilde{R}}\left(\tilde{g}, \tilde{Q}_{p-1}\right)\right), \\
& \left(\left(\tilde{g}, \tilde{Q}_{p}\right) \mid \mu_{\tilde{R}}\left(\tilde{g}, \tilde{Q}_{p}\right)\right), \\
& \left(\left(\tilde{g}, \tilde{Q}_{p+1}\right) \mid \mu_{\tilde{R}}\left(\tilde{g}, \tilde{Q}_{p+1}\right)\right), \ldots, \\
& \left.\left(\left(\tilde{g}, \tilde{Q}_{p+n_{i}}\right) \mid \mu_{\tilde{R}}\left(\tilde{g}, \tilde{Q}_{p+n_{i}}\right)\right)\right\}
\end{aligned}
$$


Keempat, setelah diketahui $\mu_{\tilde{R}}\left(\tilde{g}, \tilde{Q}_{i}\right)$, dicari hasil perkalian derajat keanggotaan ketebalan titik yang diproyeksikan $\mu_{\tilde{g}}$ dan derajat keanggotaan relasi $\mu_{\tilde{R}}\left(\tilde{g}, \tilde{Q}_{i}\right)$, yang didefinisikan dengan $\mu_{k}\left(\tilde{g}, \tilde{Q}_{i}\right)$. Selanjutnya mencari derajat keanggotaan ketebalan masing-masing titik hasil proyeksi $\left(\mu_{\widetilde{g}}\left(\tilde{g}, \widetilde{Q}_{i}\right)\right)$, yang merupakan irisan (intersection) dari $\mu_{k}\left(\tilde{g}, \widetilde{Q}_{i}\right)$ dengan $\mu_{\widetilde{V}}$.

$$
\begin{array}{ll}
\mu_{\tilde{g}^{\top}}\left(\tilde{g}, \tilde{Q}_{p-n_{i}}\right) & =\min \left(\mu_{k}\left(\tilde{g}, \tilde{Q}_{p-n_{i}}\right), \mu_{\widetilde{V}}\right) \\
\vdots & \\
\mu_{\widetilde{g^{\prime}}}\left(\tilde{g}, \tilde{Q}_{p-1}\right) & =\min \left(\mu_{k}\left(\tilde{g}, \tilde{Q}_{p-1}\right), \mu_{\widetilde{V}}\right) \\
\mu_{\widetilde{g}^{\top}}\left(\tilde{g}, \tilde{Q}_{p}\right) & =\min \left(\mu_{k}\left(\tilde{g}, \tilde{Q}_{p}\right), \mu_{\widetilde{V}}\right) \\
\mu_{\tilde{g}^{\prime}}\left(\tilde{g}, \tilde{Q}_{p+1}\right) & =\min \left(\mu_{k}\left(\tilde{g}, \tilde{Q}_{p+1}\right), \mu_{\widetilde{V}}\right) \\
\vdots & \\
\mu_{\widetilde{g^{\prime}}}\left(\tilde{g}, \tilde{Q}_{p+n_{i}}\right) & =\min \left(\mu_{k}\left(\tilde{g}, \tilde{Q}_{p+n_{i}}\right), \mu_{\widetilde{V}}\right)
\end{array}
$$

Jadi didapatkan hasil proyeksi berupa bidang $\widetilde{g}^{\prime} \in \tilde{V}$ dengan

$$
\tilde{g}^{\prime} \equiv\left\{A x+B y+C z+D=0 \mid \mu_{\widetilde{g^{\prime}}}\right\}
$$

dengan koordinat yang sama dengan bidang proyektor $\tilde{V}$, dan dengan $\mu_{\widetilde{g}^{\prime}}$ sebagai berikut:

$$
\begin{aligned}
\mu_{\widetilde{g}^{\prime}}\left(\tilde{g}, \widetilde{Q}_{i}\right) & =\left\{\left(\left(\tilde{g}, \tilde{Q}_{p-n_{i}}\right) \mid \mu_{\tilde{g}^{\top}}\left(\tilde{g}, \widetilde{Q}_{p-n_{i}}\right)\right), \ldots,\right. \\
& \left(\left(\tilde{g}, \tilde{Q}_{p-1}\right) \mid \mu_{\widetilde{g}^{\prime}}\left(\tilde{g}, \tilde{Q}_{p-1}\right)\right) \\
& \left(\left(\tilde{g}, \tilde{Q}_{p}\right) \mid \mu_{\widetilde{g}^{\prime}}\left(\tilde{g}, \tilde{Q}_{p}\right)\right) \\
& \left(\left(\tilde{g}, \tilde{Q}_{p+1}\right) \mid \mu_{\widetilde{g}^{\prime}}\left(\tilde{g}, \tilde{Q}_{p+1}\right)\right), \ldots, \\
& \left.\left(\left(\tilde{g}, \tilde{Q}_{p+n_{i}}\right) \mid \mu_{\widetilde{g}^{\prime}}\left(\tilde{g}, \tilde{Q}_{p+n_{i}}\right)\right)\right\}
\end{aligned}
$$

\section{b. Proyeksi Garis Fuzzy $\widetilde{g}$ pada Bidang Fuzzy $\widetilde{V}$ Jika Garis $\widetilde{g}$ Saling Sejajar dengan Bidang $\widetilde{V}$}

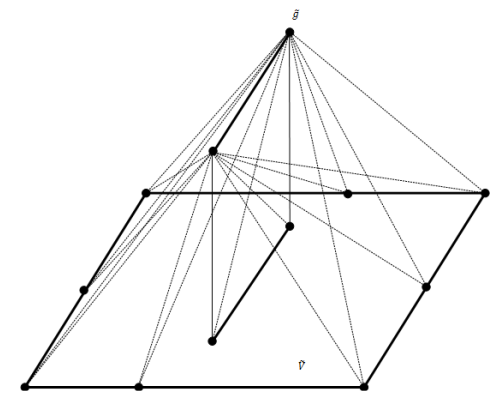

Gambar 9. Proyeksi Garis Fuzzy g pada Bidang Fuzzy $\tilde{V}$ yang Saling Sejajar

Misal sebuah garis fuzzy $\tilde{g}$ diproyeksikan terhadap bidang fuzzy $\tilde{V}$, untuk mengetahui hasil proyeksinya, dapat dicari dengan langkahlangkah sebagai berikut:

Pertama, diberikan garis fuzzy $\tilde{g}$ sebagai unsur yang diproyeksikan dan bidang fuzzy $\tilde{V}$, sebagai unsur proyektor.

Kedua, dicari jarak terdekat antara garis fuzzy $\tilde{g}$ dengan bidang fuzzy $\tilde{V}$, yang dinotasikan $v$ dengan syarat $v$ merupakan panjang garis fuzzy hubung $\tilde{g}$ dengan bidang fuzzy $\tilde{V}$, dimana $v$ tegak lurus dengan garis fuzzy $\tilde{g}$ dan bidang fuzzy $\tilde{V}$, setelah itu mencari jarak antara titik $\tilde{g}_{i} \in \tilde{g}$ dengan titik fuzzy $\tilde{Q}_{i}$ (titik-titik fuzzy pada bidang fuzzy $\left.\tilde{V}, \tilde{Q}_{i} \in \tilde{V}\right)$.

Ketiga, dicari derajat keanggotaan relasi antara titik $\widetilde{g}_{l} \in \tilde{g}$ dengan bidang fuzzy $\tilde{V}$ yang didefinisikan dengan $\left(\mu_{\tilde{R}}\right)$, dimana $\widetilde{R}$ merupakan relasi dari titik-titik fuzzy pada $\tilde{g}$ terhadap bidang fuzzy $\tilde{V},(\tilde{R} \subset \tilde{g} \times \tilde{V})$.

$$
\tilde{R}=\left[\left\{\left(\tilde{g}_{i}, \tilde{Q}_{i}\right) \mid \mu_{\tilde{R}}\left(\tilde{g}_{i}, \tilde{Q}_{i}\right)\right\} \mid\left(\tilde{g}_{i}, \tilde{Q}_{i}\right) \in \tilde{g} \times \tilde{V}\right]
$$

Derajat keanggotaan relasi $\left(\mu_{\tilde{R}}\right)$ bisa diketahui dengan fungsi berikut:

$$
\mu_{\tilde{R}}\left(\tilde{P}, \tilde{Q}_{i}\right)=e^{-\left(w_{i}-v\right)^{0,5}}
$$

dimana

$$
\begin{aligned}
& v=\text { Jarak terdekat garis } \tilde{g} \text { pada bidang } \tilde{V} \\
& w_{i}=\text { Jarak titik } \tilde{g} \text { dengan } \tilde{Q}_{i}
\end{aligned}
$$

Derajat keanggotaan relasi tersebut merupakan representasi dari seberapa besar atau kuat relasi antara titik fuzzy $\tilde{g}_{i}$ dengan bidang fuzzy $\tilde{V}$, dengan berasumsi jika jarak antara titik fuzzy $\tilde{g}_{i}$ dengan $\tilde{Q}_{i} \in \tilde{V}$ semakin dekat, maka kekuatan $\mu_{\tilde{R}}$ semakin besar. Sedangkan jika jarak antara titik fuzzy $\tilde{g}_{i}$ dengan $\tilde{Q}_{i}$ semakin juah, maka berlaku sebaliknya yaitu kekuatan $\mu_{\tilde{R}}$ semakin kecil, akan tetapi kekuatan masing-masing relasi tersebut masih berada pada interval $[0,1]$.

Relasi tersebut dapat digambar ke dalam tabel berikut

Tabel 4. Tabel Matriks Relasi Garis Fuzzy $\tilde{g}$ dengan Bidang Fuzzy $\tilde{V}$, dimana $\tilde{g}$ Sejajar $\tilde{V}$, $\left(\mu_{\tilde{R}}\left(\tilde{g}_{i}, \tilde{Q}_{i}\right)\right)$

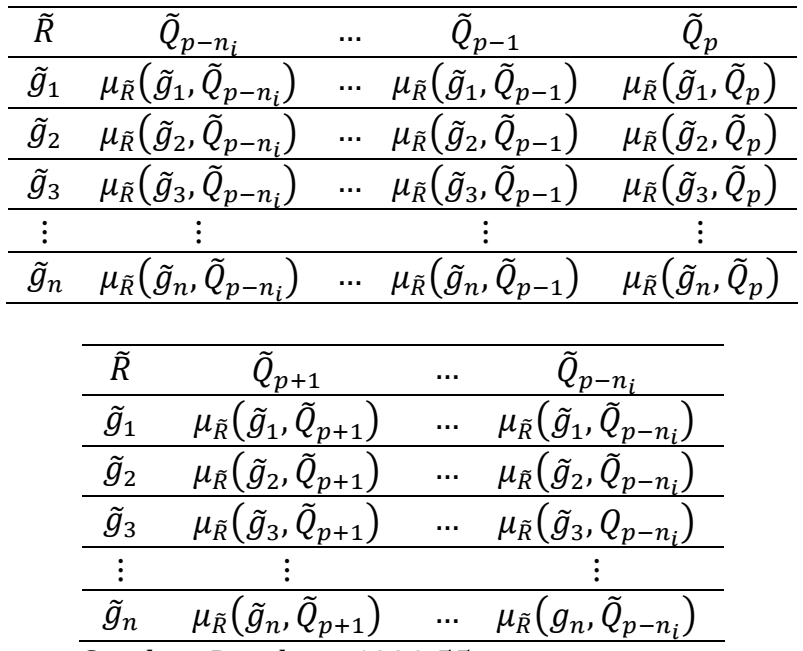

\section{Sumber: Djauhari, 1990:55}

Sehingga diperoleh derajat keanggotaan relasi garis fuzzy $\tilde{g}$ pada bidang fuzzy $\tilde{V}$ dengan $\mu_{\tilde{R}}\left(\tilde{g}, \widetilde{Q}_{i}\right)$ sebagai berikut: 


$$
\begin{aligned}
\mu_{\tilde{R}}\left(\tilde{g}, \widetilde{Q}_{i}\right)= & \left\{\left(\left(\tilde{g}, \tilde{Q}_{p-n_{i}}\right) \mid 1\right), \ldots,\left(\left(\tilde{g}, \widetilde{Q}_{p-1}\right) \mid 1\right),\right. \\
& \left(\left(\tilde{g}, \tilde{Q}_{p}\right) \mid 1\right),\left(\left(\tilde{g}, \tilde{Q}_{p+1}\right) \mid 1\right), \ldots, \\
& \left.\left(\left(\tilde{g}, \tilde{Q}_{p+n_{i}}\right) \mid 1\right)\right\}
\end{aligned}
$$

dimana $\mu_{\tilde{R}}\left(\tilde{g}_{i}, \tilde{Q}_{i}\right)=1$, terjadi ketika relasi antara titik fuzzy $\tilde{g}_{i}$ dan titik fuzzy $\tilde{Q}_{i}$ bernilai sama dimana $w_{i}=v$, sehingga harga maksimum dari $\mu_{\tilde{R}}\left(\tilde{g}_{i}, \tilde{Q}_{i}\right)$ yang relatif terhadap variabel $\tilde{g}_{i}$ bernilai 1 .

Keempat, setelah diketahui $\mu_{\tilde{R}}\left(\tilde{g}, \tilde{Q}_{i}\right)$, dicari hasil perkalian derajat keanggotaan ketebalan titik yang diproyeksikan $\mu_{\tilde{g}}$ dan derajat keanggotaan relasi $\mu_{\tilde{R}}\left(\tilde{g}, \tilde{Q}_{i}\right)$, yang didefinisikan dengan $\mu_{k}\left(\tilde{g}, \tilde{Q}_{i}\right)$. Selanjutnya mencari derajat keanggotaan ketebalan masing-masing titik hasil proyeksi $\left(\mu_{\widetilde{g} \prime}\left(\tilde{g}, \tilde{Q}_{i}\right)\right)$, yang merupakan irisan (intersection) dari $\mu_{k}\left(\tilde{g}, \widetilde{Q}_{i}\right)$ dengan $\mu_{\widetilde{V}}$.

$$
\begin{gathered}
\mu_{\tilde{g}^{\prime}}\left(\tilde{g}, \tilde{Q}_{p-n_{i}}\right)=\min \left(\mu_{\tilde{g}}, \mu_{\widetilde{V}}\right) \\
\vdots \\
\mu_{\widetilde{g}^{\prime}}\left(\tilde{g}, \tilde{Q}_{p-1}\right)=\min \left(\mu_{\tilde{g}}, \mu_{\widetilde{V}}\right) \\
\mu_{\widetilde{g}^{\top}}\left(\tilde{g}, \tilde{Q}_{p}\right)=\min \left(\mu_{\tilde{g}}, \mu_{\widetilde{V}}\right) \\
\mu_{\tilde{g}^{\top}}\left(\tilde{g}, \tilde{Q}_{p+1}\right) \quad=\min \left(\mu_{\tilde{g}}, \mu_{\widetilde{V}}\right) \\
\vdots \quad \\
\mu_{\widetilde{g}^{\prime}}\left(\tilde{g}, \tilde{Q}_{p+n_{i}}\right)=\min \left(\mu_{\tilde{g}}, \mu_{\widetilde{V}}\right)
\end{gathered}
$$

Jadi didapatkan hasil proyeksi yaitu berupa bidang $\widetilde{g^{\prime}} \in \tilde{V}$ dengan

$$
\widetilde{g}^{\prime} \equiv\left\{A x+B y+C z+D=0 \mid \mu_{\widetilde{g}^{\prime}}\right\}
$$

dengan koordinat yang sama dengan bidang proyektor $\tilde{V}$, dan dengan $\mu_{\widetilde{g}^{\prime}}$ sebagai berikut:

$$
\mu_{\widetilde{g^{\prime}}}\left(\tilde{g}, \tilde{Q}_{i}\right)=\mu_{\tilde{g}} \cap \mu_{\widetilde{V}}
$$

\section{c. Proyeksi Garis Fuzzy $\widetilde{g}$ pada Bidang Fuzzy $\widetilde{V}$ Jika Garis $\widetilde{g}$ Tidak saling Tegak Lurus dan Tidak Saling Sejajar}

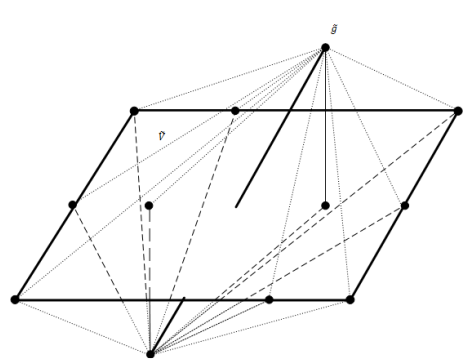

Gambar 10. Proyeksi Garis Fuzzy $\tilde{g}$ pada Bidang Fuzzy $\tilde{V}$ yang Tidak Saling Tegak Lurus dan Tidak Saling Sejajar

Misal sebuah garis fuzzy $\tilde{g}$ diproyeksikan terhadap bidang fuzzy $\tilde{V}$, untuk mengetahui hasil proyeksinya, dapat dicari dengan langkahlangkah sebagai berikut:

Pertama, diberikan garis fuzzy $\tilde{g}$ sebagai unsur yang diproyeksikan dan bidang fuzzy $\tilde{V}$, sebagai unsur proyektor.
Kedua, dicari jarak terdekat antara garis fuzzy $\tilde{g}$ dengan bidang fuzzy $\tilde{V}$, yang dinotasikan $v$ dengan syarat $v$ merupakan panjang garis fuzzy hubung $\tilde{g}$ dengan bidang fuzzy $\tilde{V}$, dimana $v$ tidak berpotongan dengan bidang fuzzy $\tilde{V}$. Jika garis fuzzy $g$ berpotongan dengan bidang fuzzy $\tilde{V}$, maka $v$ bernilai 0 , setelah itu mencari jarak antara titik $\tilde{g}_{i} \in \tilde{g}$ dengan titik fuzzy $\tilde{Q}_{i}$ (titik-titik fuzzy pada bidang fuzzy $\tilde{V}, \tilde{Q}_{i} \in \tilde{V}$ ).

Ketiga, dicari derajat keanggotaan relasi antara titik $\widetilde{g}_{\imath} \in \tilde{g}$ dengan bidang fuzzy $\tilde{V}$ yang didefinisikan dengan $\left(\mu_{\tilde{R}}\right)$, dimana $\widetilde{R}$ merupakan relasi dari titik-titik fuzzy pada $\tilde{g}$ terhadap bidang fuzzy $\tilde{V},(\tilde{R} \subset \tilde{g} \times \tilde{V})$.

$$
\tilde{R}=\left[\left\{\left(\tilde{g}_{i}, \tilde{Q}_{i}\right) \mid \mu_{\tilde{R}}\left(\tilde{g}_{i}, \tilde{Q}_{i}\right)\right\} \mid\left(\tilde{g}_{i}, \tilde{Q}_{i}\right) \in \tilde{g} \times \tilde{V}\right]
$$

Derajat keanggotaan relasi $\left(\mu_{\tilde{R}}\right)$ bisa diketahui dengan fungsi berikut:

$$
\mu_{\tilde{R}}\left(\widetilde{P}, \tilde{Q}_{i}\right)=e^{-\left(w_{i}-v\right)^{0,5}}
$$

dimana

$$
v=\text { Jarak terdekat garis } \tilde{g} \text { pada bidang } \tilde{V}
$$

$w_{i}=$ Jarak antara titik $\tilde{g}$ dengan $\tilde{Q}_{i}$

Derajat keanggotaan relasi tersebut merupakan representasi dari seberapa besar atau kuat relasi antara titik fuzzy $\tilde{g}_{i}$ dengan bidang

\begin{tabular}{|c|c|c|c|c|}
\hline$\tilde{R}$ & $\tilde{Q}_{p-n_{i}}$ & $\ldots$ & $\tilde{Q}_{p-1}$ & $\tilde{Q}_{p}$ \\
\hline$\tilde{g}_{1}$ & $\mu_{\tilde{R}}\left(\tilde{g}_{1}, \tilde{Q}_{p-n_{i}}\right)$ & $\ldots$ & $\mu_{\tilde{R}}\left(\tilde{g}_{1}, \tilde{Q}_{p-1}\right)$ & $\mu_{\tilde{R}}\left(\tilde{g}_{1}, \tilde{Q}\right.$ \\
\hline$\tilde{g}_{2}$ & $\mu_{\tilde{R}}\left(\tilde{g}_{2}, \tilde{Q}_{p-n_{i}}\right)$ & $\ldots$ & $\mu_{\tilde{R}}\left(\tilde{g}_{2}, \tilde{Q}_{p-1}\right)$ & $\mu_{\tilde{R}}\left(\tilde{g}_{2}, \tilde{Q}\right.$ \\
\hline$\tilde{g}_{3}$ & $\mu_{\tilde{R}}\left(\tilde{g}_{3}, \tilde{Q}_{p-n_{i}}\right)$ & $\ldots$ & $\mu_{\tilde{R}}\left(\tilde{g}_{3}, \tilde{Q}_{p-1}\right)$ & $\mu_{\tilde{R}}\left(\tilde{g}_{3}, \hat{Q}\right.$ \\
\hline$\vdots$ & & & $\vdots$ & \\
\hline$\tilde{g}_{n}$ & $\mu_{\tilde{R}}\left(\tilde{g}_{n}, \tilde{Q}_{p-n_{i}}\right)$ & $\cdots \quad$ & $\mu_{\tilde{R}}\left(\tilde{g}_{n}, \widetilde{Q}_{p-1}\right)$ & $\mu_{\tilde{R}}\left(\tilde{g}_{n}, \mathcal{C}\right.$ \\
\hline & $\tilde{Q}_{p+}$ & & $\tilde{Q}$ & \\
\hline & $\mu_{\tilde{R}}\left(\tilde{g}_{1}, C\right.$ & $p+1)$ & $\cdots \quad \mu_{\tilde{R}}(\tilde{g}$ & $\left.\tilde{Q}_{p-n_{i}}\right)$ \\
\hline & $\mu_{\tilde{R}}\left(\tilde{g}_{2}, C\right.$ & & $\cdots \quad \mu_{\tilde{R}}(\tilde{g}$ & $\left.\tilde{Q}_{p-n_{i}}\right)$ \\
\hline & $\mu_{\tilde{R}}\left(\tilde{g}_{3}, C\right.$ & $p+1)$ & $\cdots \quad \mu_{\tilde{R}}(\tilde{g}$ & $\left.Q_{p-n_{i}}\right)$ \\
\hline & $\vdots$ & & & \\
\hline & $\mu_{\tilde{R}}\left(\tilde{g}_{n}\right.$, & $p+1)$ & $\cdots \quad \mu_{\tilde{R}}($ & $\left.\tilde{Q}_{p-n_{i}}\right)$ \\
\hline
\end{tabular}
fuzzy $\tilde{V}$, dengan berasumsi jika jarak antara titik fuzzy $\tilde{g}_{i}$ dengan $\tilde{Q}_{i} \in \tilde{V}$ semakin dekat, maka kekuatan $\mu_{\tilde{R}}$ semakin besar. Sedangkan jika jarak antara titik fuzzy $\tilde{g}_{i}$ dengan $\tilde{Q}_{i}$ semakin juah, maka berlaku sebaliknya yaitu kekuatan $\mu_{\tilde{R}}$ semakin kecil, akan tetapi kekuatan masing-masing relasi tersebut masih berada pada interval $[0,1]$.

Relasi tersebut dapat digambar ke dalam tabel berikut

Tabel 5. Tabel Matriks Relasi Garis Fuzzy $\tilde{g}$ dan Bidang Fuzzy $\tilde{V}$, dimana $\tilde{g}$ Tidak Tegak Lurus dan Tidak Sejajar $\tilde{V}, \mu_{\tilde{R}}\left(\tilde{g}_{i}, \tilde{Q}_{i}\right)$

Sumber: Djauhari, 1990:55 
Sehingga diperoleh derajat keanggotaan relasi garis fuzzy $\tilde{g}$ pada bidang fuzzy $\tilde{V}$ dengan $\mu_{\tilde{R}}\left(\tilde{g}, \widetilde{Q}_{i}\right)$ sebagai berikut:

$$
\begin{aligned}
\mu_{\tilde{R}}\left(\tilde{g}, \widetilde{Q}_{i}\right)= & \left\{\left(\left(\tilde{g}, \tilde{Q}_{p-n_{i}}\right) \mid \mu_{\widetilde{R}}\left(\tilde{g}, \tilde{Q}_{p-n_{i}}\right)\right), \ldots,\right. \\
& \left(\left(\tilde{g}, \tilde{Q}_{p-1}\right) \mid \mu_{\tilde{R}}\left(\tilde{g}, \tilde{Q}_{p-1}\right)\right), \\
& \left(\left(\tilde{g}, \tilde{Q}_{p}\right) \mid \mu_{\tilde{R}}\left(\tilde{g}, \tilde{Q}_{p}\right)\right) \\
& \left(\left(\tilde{g}, \tilde{Q}_{p+1}\right) \mid \mu_{\tilde{R}}\left(\tilde{g}, \tilde{Q}_{p+1}\right)\right), \ldots, \\
& \left.\left(\left(\tilde{g}, \tilde{Q}_{p+n_{i}}\right) \mid \mu_{\tilde{R}}\left(\tilde{g}, \tilde{Q}_{p+n_{i}}\right)\right)\right\}
\end{aligned}
$$

Keempat, setelah diketahui $\mu_{\tilde{R}}\left(\tilde{g}, \widetilde{Q}_{i}\right)$, dicari hasil perkalian derajat keanggotaan ketebalan titik yang diproyeksikan $\mu_{\tilde{g}}$ dan derajat keanggotaan relasi $\mu_{\tilde{R}}\left(\tilde{g}, \widetilde{Q}_{i}\right)$, yang didefinisikan dengan $\mu_{k}\left(\tilde{g}, \tilde{Q}_{i}\right)$. Selanjutnya mencari derajat keanggotaan ketebalan masing-masing titik hasil proyeksi $\left(\mu_{\widetilde{g}}\left(\tilde{g}, \tilde{Q}_{i}\right)\right)$, yang merupakan irisan (intersection) dari $\mu_{k}\left(\tilde{g}, \widetilde{Q}_{i}\right)$ dengan $\mu_{\widetilde{V}}$.

$$
\begin{aligned}
& \left.\mu_{\widetilde{g^{\prime}}}\left(\tilde{g}, \tilde{Q}_{p-n_{i}}\right)=\min \left(\mu_{k}\left(\tilde{g}, \tilde{Q}_{p-n_{i}}\right), \mu_{\widetilde{V}}\right)\right) \\
& \mu_{\widetilde{g^{\prime}}}\left(\tilde{g}, \tilde{Q}_{p-1}\right)=\min \left(\mu_{k}\left(\tilde{g}, \widetilde{Q}_{p-1}\right), \mu_{\widetilde{V}}\right) \\
& \mu_{\widetilde{g^{\prime}}}\left(\tilde{g}, \tilde{Q}_{p}\right)=\min \left(\mu_{k}\left(\tilde{g}, \tilde{Q}_{p}\right), \mu_{\widetilde{V}}\right) \\
& \mu_{\widetilde{g}^{\top}}\left(\tilde{g}, \tilde{Q}_{p+1}\right)=\min \left(\mu_{k}\left(\tilde{g}, \tilde{Q}_{p+1}\right), \mu_{\widetilde{V}}\right) \\
& \mu_{\widetilde{g^{\prime}}}\left(\tilde{g}, \tilde{Q}_{p+n_{i}}\right)=\min \left(\mu_{k}\left(\tilde{g}, \tilde{Q}_{p+n_{i}}\right), \mu_{\widetilde{V}}\right)
\end{aligned}
$$

Jadi didapatkan hasil proyeksi berupa bidang $\widetilde{g^{\prime}} \in \tilde{V}$ dengan

$$
\widetilde{g^{\prime}} \equiv\left\{A x+B y+C z+D=0 \mid \mu_{\widetilde{g^{\prime}}}\right\}
$$

dengan koordinat yang sama dengan bidang proyektor $\tilde{V}$, dan dengan $\mu_{\widetilde{g}^{\prime}}$ sebagai berikut:

$$
\begin{aligned}
\mu_{\widetilde{g}^{\prime}} & \left(\tilde{g}, \widetilde{Q}_{i}\right)=\left\{\left(\left(\tilde{g}, \tilde{Q}_{p-n_{i}}\right) \mid \mu_{\widetilde{g^{\prime}}}\left(\tilde{g}, \widetilde{Q}_{p-n_{i}}\right)\right), \ldots,\right. \\
& \left(\left(\tilde{g}, \tilde{Q}_{p-1}\right) \mid \mu_{\widetilde{g^{\prime}}}\left(\tilde{g}, \widetilde{Q}_{p-1}\right)\right), \\
& \left(\left(\tilde{g}, \tilde{Q}_{p}\right) \mid \mu_{\widetilde{g^{\prime}}}\left(\tilde{g}, \widetilde{Q}_{p}\right)\right) \\
& \left(\left(\tilde{g}, \tilde{Q}_{p+1}\right) \mid \mu_{\widetilde{g^{\prime}}}\left(\tilde{g}, \widetilde{Q}_{p+1}\right)\right), \ldots, \\
& \left.\left(\left(\tilde{g}, \tilde{Q}_{p+n_{i}}\right) \mid \mu_{\widetilde{g^{\prime}}}\left(\tilde{g}, \widetilde{Q}_{p+n_{i}}\right)\right)\right\}
\end{aligned}
$$

\section{PENUTUP}

Perbedaan proyeksi geometri tegas dan proyeksi geometri fuzzy yaitu pada proyeksi geometri tegas unsur yang diproyeksikan dan unsur proyektor hanya bersifat bivalue, yaitu ada dan tidak ada. Sedangkan pada proyeksi geometri fuzzy unsur geometri bersifat multivalue, dengan ketebalan yang yang direpresentasikan dengan derajat keanggotaan dalam interval $[0,1]$. Pada proyeksi geometri fuzzy cenderung lebih global dibandingkan dengan proyeksi geometri tegas karena pada proyeksi geometri tegas terdapat syarat tegak lurus antara unsur yang diproyeksikan dengan unsur proyektor, sehingga hasil proyeksi terbatas antara ada dan tidak adanya hasil proyeksinya pada syarat tersebut, sedangkan pada geometri fuzzy semua anggota unsur proyektor dianggap sebagai hasil dari unsur yang diproyeksikan tersebut dengan derajat keanggotaan ketebalan tertentu. Derajat keanggotaan ketebalan tersebut dipengaruhi oleh derajat keanggotaan kekuatan relasi antara unsur-unsur yang diproyeksikan dan unsurunsur proyektor.

\section{DAFTAR PUSTAKA}

[1] Alisah, E. \& Idris. 2009. Buku Pintar Matematika. Jogjakarta: Mitra Pelajar.

[2] Casse, R. 2006. Projective Geometry An Introduction. New York: Oxford University Press Inc.

[3] Djauhari, M. 1990. Himpunan Fuzzy. Jakarta: Karunika Universitas Terbuka.

[4] Krismanto. 2008. Pembelajaran Sudut dan Jarak dalam Ruang Dimensi Tiga di SMA. Yogyakarta: Pusat Pengembangan dan Pemberdayaan Pendidik dan Tenaga Kependidikan Matematika.

[5] Kusumadewi, S. 2002. Analisis \& Desain Sistem Fuzzy Menggunakan Toolbox Matlab. Yogyakarta: Graha Ilmu.

[6] Kusumadewi, S. dkk. 2006. Fuzzy MultiAttribute Decision Making. Yogyakarta: Graha Ilmu.

[7] Kusumadewi, S. \& Purnomo, H. 2004. Aplikasi Logika Fuzzy untuk Pendukung Keputusan. Yogyakarta: Graha Ilmu.

[8] Larson, R. \& Edwards, B. H. 2010. Calculus. Belmont: Cengage Learning.

[9] Rich, B. 2002. Geometri. Jakarta: Erlangga

[10] Soebari. 1995. Geometri Analitik. Malang: FMIPA IKIP MALANG.

[11] Spiegel, R. M. 1999. Analisis Vektor. Jakarta: Erlangga.

[12] Stein, K. S. \& Barchellos, A. 1992. Calculus and Analytic Geometry. US: Mc.Graw Hill.

[13] Sundawa, D. 2009. Teorema Pythagoras dan Garis-Garis pada Segitiga. (Online: http://www.crayonpedia.org/mw/BSE:Teor ema Pythagoras dan Garis-Garis pada Segitiga 8.1 (BAB 5). diakses 7 Mei 2012).

[14] Susilo, F. 2006. Himpunan dan Logika Fuzzy serta Aplikasinya. Yogyakarta: Graha Ilmu. 